\title{
PENGARUH PROFITABILITAS, LEVERAGE DAN GROWTH TERHADAP KEBIJAKAN DEVIDEN PADA PERUSAHAAN MANUFAKTUR YANG TERDAFTAR DI BURSA EFEK INDONESIA
}

\section{THE EFFECT OF PROFITABILITAS, LEVERAGE AND GROWTH ON THE POLICIES DEVIDEN OF MANUFACTURING INDUSTRI COMPANIES LISTED ON THE INDONESIA STOCK EXCHANGE}

\author{
Renny Mointi ${ }^{1}$, Rina $^{2}$ \\ Manajemen, Sekolah Tinggi Ilmu Manajemen LPI Makassar \\ 1(rennymointi@gmail.com), ${ }^{2}$ (rinajanny78@gmail.com)
}

\begin{abstract}
ABSTRAK
Penelitian ini bertujuan untuk menganalisis pengaruh Profitabilitas yang diwakili rasio return on Investment, Leverage yang diwakili rasio Debt to Equity Ratio dan Growth terhadap Kebijakan Deviden (Deviden Payout Ratio) pada perusahaan Manufaktur yang terdaftar di Bursa Efek Indonesia. Sampel yang digunakan dalam penelitian ini berjumlah 5 perusahaan dan menggunakan data tahun 2013 hingga 2018. Analisis data menggunakan regresi berganda dengan dan uji asumsi klasik yang meliputi uji normalitas uji multikolonieritas dan uji autokorelasi. Hasil analisis parsial dengan uji t dan uji F menyimpulkan bahwa variabel Profitabilitas (ROI) berpengaruh tidak signifikan terhadap Kebijakan Deviden, Leverage (DER) berpengaruh tidak signifikan terhadap kebijakan Deviden, Variabel Return on investment, Debt to Equity ratio dan growth dapat menjelaskan $15,9 \%$ variasi tinggi rendahnya kebijakan deviden selebihnya $84,1 \%$ ditentukan oleh variabel lain yang tidak tercakup dalam penelitian ini. Implikasi hasil penelitian ini bahwa Return variabel Return On Investment, Debt To Equity Ratio dan Growth tidak dapat digunakan sebagai indikator dalam menentukan kebijakan deviden suatu perusahaan.
\end{abstract}

Kata Kunci: Kebijakan deviden, Profitabilitas, Leverage dan Growth

\section{ABSTRACT}

This study aims to analyze the effect of profitability represented by the ratio of Return On Investment, Leverage represented by the ratio of Debt to Equity Ratio and Growth to Dividend Policy (Dividend Payout Ratio) on Manufacturing companies listed on the Indonesia Stock Exchange. The sample used in this study amounted to 5 companies and used data from 2013 to 2018. Data analysis used multiple regression and classic assumption tests which included normality tests of multicollinearity tests and autocorrelation tests. The results of the partial analysis with the test and $F$ test concluded that the variable Profitability (ROI) did not have a significant effect on the Dividend Leverage Policy (DER). It did not have a significant effect on the variable dividend policy. Return on investment the low dividend policy of the remaining $84.1 \%$ determined by other variables not covered in this study. The implication of the results of this study is that Return on investment debt to equity ratio and Growth variable returns cannot be used as an indicator in determining a company's dividend policy

Keywords: Dividend policy, Profitability, Leverage and Growth

\section{PENDAHULUAN}

Kebijakan deviden merupakan salah satu kebijakan dalam perusahaan yang harus diperhatikan dan dipertimbangkan secara seksama. Dalam kebijakan dividen ditentukan jumlah alokasi laba yang dapat 
dibagikan kepada para pemegang saham (deviden) dan alokasi laba yang dapat ditahan perusahaan. Semakin besar laba yang ditahan, semakin kecil laba yang akan dibagikan pada para pemegang saham. Dalam pengalokasian laba tersebut timbullah berbagai masalah yang dihadapi.

Prihantoro (2003) mengungkapkan para pemegang saham mempunyai tujuan utama untuk meningkatkan kesejahteraan yaitu mengharapkan pengembalian dalam bentuk deviden maupun capital gain. Dilain pihak, perusahaan juga mengharapkan adanya pertumbuhan secara terus menerus untuk mempertahankan kelangsungan hidupnya.

Berdasarkan pernyataan tersebut dapat diketahui bahwa investor menginginkan kebijakan dividen yang stabil. Namun kenyataannya, rata-rata perkembangan dividen payout ratio selama periode 2005-2010

Pendanaan perusahaan melalui hutang erat kaitannya dengan struktur modal dan hutang dalam hal ini leverage merupakan sumber pendanaan eksternal (external financing) untuk membiayai kegiatan perusahaan. Apabila leverage rendah, berarti perusahaan memiliki jumlah utang relatif sedikit daripada modal sendiri, hal ini akan berpengaruh terhadap perolehan laba. Perusahaan yang memperoleh laba bersih sebelum pajak dalam jumlah yang tinggi maka laba yang dibagikan kepada pemegang saham akan semakin tinggi yang pada akhirnya dividen yang dibayarkan akan semakin tinggi (Darminto,2008).

Pembagian dividen perusahaan juga dipengaruhi kebijakan investasi perusahaan. Namun laba yang diperoleh perusahaan digunakan untuk mendanai investasi perusahaan, akan mengurangi proporsi deviden yang akan dibayarkan kepada pemegang saham. Semakin besar laba yang ditahan untuk pertumbuhan perusahaan semakin kecil pula dividen yang dibayarkan. Proksi pertumbuhan yang digunakan dalam penelitian ini adalah growth.
Beberapa faktor yang mempengaruhi besar kecilnya deviden yang akan dibayarkan oleh perusahaan kepada pemegang saham antara lain adalah posisi solvabilitas perusahaan, posisi likuiditas perusahaan, kebutuhan untuk melunasi hutang, rencana perluasan, kesempatan lnvestasi, stabilitas pendapatan, pengawasan terhadap perusahaan (Sutrisno,2003:304).

Profitabilitas mempengaruhi kebijakan dividen dikarenakan profitabilitas merupakan kemampuan perusahaan untuk menghasilkan laba dan dividen akan dibagi apabila perusahaan tersebut memperoleh laba. Manajemen akan membayarkan dividen untuk memberikan sinyal mengenai keberhasilan perusahaan dalam membukukan profit. Sinyal tersebut menyimpulkan bahwa kemampuan perusahaan untuk membayar dividen merupakan fungsi dari keuntungan. Perusahaan yang memperoleh keuntungan cenderung akan membayar porsi keuntungannya lebih besar sebagai dividen. Semakin besar keuntungan yang diperoleh maka akan semakin besar pula kemampuan perusahaan untuk membayar dividen. Dengan demikian profitabilitas mutlak diperlukan untuk perusahaan apabila hendak membayar dividen.

Asimetri informasi menyebabkan pendanaan ekternal terlalu mahal bagi perusahaan, karena itu perusahaan lebih memprioritaskan dana internal dari pada ekternal. Apabila dana internal tidak mencukupi, maka perusahaan dituntut untuk leverage perusahaan digunakan untuk pembayaran dividen agar dapat menjaga performa dan signal perusahaan bagi investor (Sulistyowati dkk, 2010).

Tingkat pertumbuhan perusahaan merupakan salah satu faktor yang mempengaruhi kebijakan dividen. Semakin cepat tingkat pertumbuhan suatu perusahaan, maka semakin besar kebutuhan dana yang diperlukan untuk 
membiayai pertumbuhan tersebut. Semakin besar kebutuhan dana untuk waktu mendatangmaka perusahaan lebih senang untuk menahan labanya dari pada membayarkannya sebagai dividen kepada pemegang saham.

Penelitian yang dilakukan oleh Darminto (2008) meneliti mengenai pengaruh Profitabilitas, Likuiditas, Struktur Modal, dan Struktur Kepemilikan Saham terhadap Kebijakan Deviden. Secara parsial variabel profitabilitas berpengaruh positif dan signifikan, struktur modal berpengaruh negatif dan signifikan, variabel likuiditas berpengaruh positif dan tidak signifikan sedangkan struktur kepemilikan saham berpengaruh positif dan tidak signifikan terhadap kebijakan dividen.

Adapun tujuan yang ingin dicapai dalam penelitian ini adalah untuk menganalisis pengaruh profitabilitas terhadap kebijakan dividen pada perusahaan manufaktur di Bursa Efek Indonesia, untuk menganalisis pengaruh leverage terhadap kebijakan dividen pada perusahaan manufaktur di Bursa Efek Indonesia, dan untuk menganalisis pengaruh growth terhadap kebijakan dividen pada perusahaan manufaktur di Bursa Efek Indonesia.

\section{METODE}

Penelitian ini dilakukan pada Pusat Informasi Pasar Modal (PIPM) Makassar yang beralamat di Jalan AP. Pettarani A 30 Makassar. Penelitian dilakukan dalam waktu 1 bulan. Pendekatan penelitian yang digunakan dalam penelitian ini merupakan pendekatan kuantitatif di mana berupa data yang dipergunakan dalam bentuk angka berupa data laporan neraca dan laporan rugi laba pada perusahaan manufaktur yang terdaftar di Bursa Efek Indonesia.

Populasi dalam penelitian ini adalah seluruh perusahaan manufaktur yang terdaftar di Bursa Efek Jakarta dalam periode 2013-2018 Jumlah populasi dalam penelitian ini adalah 127 perusahaan manufaktur. Pengambilan sampel dilakukan dengan metode purposive sampling dengan tujuan untuk mendapatkan sampel yang representatif dengan kriteria sebagai berikut:

a. Perusahaan manufaktur yang terdaftar di Bursa Efek Indonesia periode 2013-2018

b. Perusahaan tersebut membagikan deviden setiap periode 2013-2018

c. Perusahaan tersebut menyajikan laporan keuangan setiap periode pengamatan yaitu periode 2013-2018.

Jumlah sampel yang memenuhi kriteria dalam penelitian ini adalah sejumlah 5 perusahaan yaitu PT. Multi Bintang Indonesia Tbk., PT. Gudang Garam, Tbk. PT. Sumi Indo kabel Tbk., PT. Tunas Ridean Tbk, PT. United Tractor Tbk.

Berdasarkan masalah yang akan dibahas, maka alat analisis yang akan digunakan adalah Regresi Berganda dengan alat bantu SPSS, dengan persamaan regresi sebagai berikut:

$$
\begin{gathered}
\mathbf{Y}=\mathbf{a}+\mathbf{b} 1 \mathbf{X} \mathbf{1}+\mathbf{b} 2 \mathbf{X} \mathbf{2}+\mathbf{b 3} \mathbf{X 3}+\mathbf{e} \\
\text { Keterangan : } \\
\mathrm{Y}=\text { Kebijakan Deviden }(\mathrm{DPR}) \\
\mathrm{a}=\text { konstanta } \\
\text { b1 }=\text { koefisien variable X1 } \\
\mathrm{X} 1=\text { Profitabilitas } \\
\mathrm{b} 2=\text { koefisien variable X2 } \\
\mathrm{X} 2=\text { Leverage } \\
\text { b3 = koefisien variable X3 } \\
\mathrm{X} 3=\text { Growth } \\
\mathrm{e}=\text { Error Term }
\end{gathered}
$$

Adapun pengujian yang dilakukan adalah Uji t (Uji Parsial) statistik yang menunjukkan seberapa jauh pengaruh satu variabel bebas secara individual dalam menerangkan variasi variabel independen (Ghozali, 2005), serta Uji statistik F (Uji Simultan) yang menunjukkan apakah semua variabel independen atau bebas yang dimasukkan dalam model mempunyai pengaruh secara bersama-sama terhadap variabel independen. 
HASIL DAN PEMBAHASAN

Dalam penelitian ini menggunakan analisis regresi linier berganda dengan bantuan SPSS versi 20 dan yang menjadi objek pene!itian yaitu Deviden Payout Ratio (DPR) (Y) sebagai variabel terikat (dependen), sementara Return On Investment (ROI) $\left(\mathrm{X}_{1}\right)$, Debt to Equity Ratio (DER) $\left(\mathrm{X}_{2}\right)$ dan Growth $\left(\mathrm{X}_{3}\right)$ sebagai variabel bebas (Independent).

\section{a. Analisis Regresi Liner Berganda}

Analisis regresi dalam penelitian ini digunakan untuk mengetahui pengaruh Return On Investment (ROI) $\left(\mathrm{X}_{1}\right)$, Debt to Equity Ratio (DER) $\left(\mathrm{X}_{2}\right)$ dan Growth $\left(\mathrm{X}_{3}\right)$ terhadap Deviden
Payout ratio (DPR). Variabel penelitian ini terdiri dari 4 variabel yaitu, variabel bebas (Independent Variable) yang terdiri dari Return On Investment (ROI) ( $\left.\mathrm{X}_{1}\right)$, Debt to Equity Ratio (DER) $\left(\mathrm{X}_{2}\right)$ dan Growth $\left(\mathrm{X}_{3}\right)$ dan variabel terikat (Dependent Variable) yaitu Deviden Payout Ratio (DPR) (Y).

\section{b. Uji t}

Hipotesis untuk menguji pengaruh variabel independen yaitu Profitabilitas (ROI) (X1), Leverage (DER) (X2) dan Growth (X3) terhadap variabel dependen yaitu Deviden Payout Ratio (DPR) (Y) dapat dilihat dari tabel berikut sebagai berikut:

Tabel 1. Koefisien Regresi

\begin{tabular}{|c|c|c|c|c|c|c|c|c|}
\hline \multirow[b]{2}{*}{ Model } & $\begin{array}{r}\text { Unstan } \\
\text { Coeff }\end{array}$ & $\begin{array}{l}\text { ardized } \\
\text { cients }\end{array}$ & $\begin{array}{l}\text { Standardi } \\
\text { zed } \\
\text { Coefficie } \\
\text { nts } \\
\end{array}$ & \multirow[b]{2}{*}{$\mathrm{T}$} & \multirow[b]{2}{*}{ Sig } & \multicolumn{3}{|c|}{ Correlations } \\
\hline & B & Std Error & Beta & & & $\begin{array}{l}\text { Zero- } \\
\text { order }\end{array}$ & Partial & Part \\
\hline (Constant) & 5,673 & 6,328 & & ,896 & ,378 & & & \\
\hline ROI & $-2,589$ & 1,268 &,- 348 & $-2,042$ & ,051 &,- 363 &,- 372 &,- 348 \\
\hline DER & $-4,164$ & 3,412 &,- 211 & $-1,220$ & ,233 &,- 258 &,- 233 &,- 208 \\
\hline GROWTH & ,227 & , 169 & ,233 & 1,347 & , 190 & ,281 & ,255 & ,229 \\
\hline
\end{tabular}

Dari tabel di atas hasil pengolahan data, maka diperoleh persamaan regresi sebagai berikut :

\section{$Y=5,673-2,589 X 1-4,164 X 2+$ $0,227 X 3$}

Berdasarkan persamaan regresi di atas, diperoleh nilai konstanta sebesar 5,673 dan variabel independen yaitu Return on Investment $\left(\mathrm{X}_{1}\right)$ dan Debt to Equity Ratio $\left(\mathrm{X}_{2}\right)$ menunjukkan tanda yang negatif, sedangkan Growth $\left(\mathrm{X}_{3}\right)$ menunjukkan tanda yang positif. Sehingga hal ini dapat diartikan bahwa jika variabel independen sama dengan nol (Return on Investment $\left(\mathrm{X}_{1}\right)$, Debt to Equity Ratio $\left(\mathrm{X}_{2}\right)$ dan Growth $\left(\mathrm{X}_{3}\right)=0$ maka besarnya variabel dependen (Deviden Payout Ratio (Y)) yaitu 5,673. Dengan kata lain, maka persamaan di atas sebagai berikut :

a. Koefisien konstanta $=5,673$ yang berarti bahwa jika variabel Return on Investment $\left(\mathrm{X}_{1}\right)$, Debt to Equity Ratio $\left(\mathrm{X}_{2}\right)$ dan Growth $\left(\mathrm{X}_{3}\right)$ sama dengan nol, maka nilai Deviden Payout ratio sebesar 5,673.

b. Koefisien regresi $X_{1}$ sebesar -2,589 menyatakan bahwa setiap peningkatan satu satuan variabel independen yaitu 
peningkatan satu satuan Return on Investment (X1) maka akan menurunkan variabel dependen yaitu Deviden Payout ratio (Y) sebesar 2,589, demikian pula sebaliknya.

c. Koefisien regresi $X_{2}$ sebesar -4, 164 menyatakan bahwa setiap peningkatan satu satuan variabel independen yaitu peningkatan satu satuan Debt to Equity Ratio (X2) maka akan menurunkan variabel dependen yaitu Deviden Payout ratio (Y) sebesar 4, 164, demikian pula sebaliknya.

d. Koefisien regresi $\mathrm{X}_{3}$ sebesar 0,227 menyatakan bahwa setiap penambahan satu satuan variabel independen yaitu peningkatan satu satuan Growth (Xs) maka akan meningkatkan variabel dependen yaitu Deviden Payout ratio $(\mathrm{Y})$ sebesar 0,227 , demikian pula sebaliknya.

Berdasarkan hasil penelitian maka diperoleh koefisien $\mathrm{t}$ hitung variabel profitabi!itas (ROI) $\left(\mathrm{X}_{1}\right)$ sebesar -2,042 $<$-t tabel sebesar -1,697 dengan signifikansi sebesar 0,051 lebih besar dari taraf signifikan 0,05 , sehingga dapat diilihat bahwa (Ho) diterima berarti variabel profitabilitas berpengaruh negatif tidak signifikan terhadap kebijakan dividen.

Koefisien $\mathrm{t}$ hitung variabel Leverage (DER) $\left(\mathrm{X}_{2}\right)$ sebesar $-1,220<\mathrm{t}$ tabel sebesar 1,697 dengan signifikansi sebesar 0,233 lebih besar dari taraf signifikan 0,05 ,sehingga dapat dilihat bahwa (Ho) diterima berarti variabel leverage berpengaruh negatif tidak signifikan terhadap kebijakan dividen.

Koefisien t hitung variabel Growth $\left(\mathrm{X}_{3}\right)$ sebesar 1,347 < t tabel sebesar 1,697 dengan signifikansi sebesar 0,190 lebih besar dari taraf signifikan 0,05 , sehingga hipotesis nol (Ho) diterima berarti variabel growth berpengaruh positif tidak signifikan terhadap kebijakan dividen.

\section{c) $\mathbf{U j i} \mathbf{F}$}

Dari hasil olah data SPSS 20.0 diperoleh variabel independen yaitu Profitabilitas (ROI) $\left(\mathrm{X}_{1}\right)$, Leverage (DER) $\quad\left(\mathrm{X}_{2}\right)$ dan Growth $\left(\mathrm{X}_{3}\right)$ terhadap variabel dependen yaitu Deviden Payout Ratio (DPR) (Y) hasil F hitung yang diperoleh sebesar 2,828 dengan tingkat signifikan sebesar 0,058 yaitu lebih besar dari 0,05 sehingga dapat dilihat bahwa Ho diterima yang menjelaskan bahwa variabel profitabilitas (ROI), Leverage (DER) dan Growth secara simultan (bersama-sama) berpengaruh tidak signifikan terhadap kebijakan dividen (DPR).

Tabel 2. Uji Signifikansi Simultan

\begin{tabular}{rlrrrrr}
\hline \multirow{2}{*}{1} & Model & $\begin{array}{c}\text { Sum of } \\
\text { Squares }\end{array}$ & Df & $\begin{array}{c}\text { Mean } \\
\text { Square }\end{array}$ & F & Sig \\
\cline { 2 - 5 } & Regression & 9.592 & 3 & 3.197 & & \\
\cline { 2 - 5 } & Residual & 29.395 & 26 & 1.131 & 2828 & 58 \\
\cline { 2 - 5 } & Total & 38.987 & 29 & & & \\
\hline \hline
\end{tabular}

Hasil analisis pengaruh nilai koefisien determinasi (Adjusted profitabilitas, leverage, dan growth $\left.\mathrm{R}^{2}\right)=0,159$ atau $15,9 \%$, ini terhadap kebijakan dividen sebagaimana berarti bahwa variabel profitabilitas, dapat dilihat pada tabel 2 menghasilkan leverage, dan growth secara simultan 
dapat menjelaskan variasi tinggi rendahnya kebijakan dividen, dan dari tabel tersebut ada 24,6\% variabel bebas yang tidak diteliti dapat menjelaskannya. Secara selektif nilai koefisien determinasi tersebut relatif rendah, mengingat dalam model ini hanya menggunakan 3 variabel bebas, yakni profitabilitas, Leverage, dan growth. Hal ini dapat diartikan bahwa variabel profitabilitas, Leverage, dan growth tidak dapat digunakan untuk memprediksi kebijakan dividen. Dengan kata lain, variabel profitabilitas, Leverage, dan growth secara simultan tidak signifikan di mana dapat diartikan variabel independen tidak dapat digunakan dalam memperdiksi kebijakan dividen. Hubungan simultan variabel profitabilitas, Leverage, dan growth terhadap kebijakan dividen seperti yang ditunjukkan oleh koefisien korelasi (Multiple R) $=0,496$, mengidentifikasi tingkat hubungan yang lemah.

Untuk menguji signifikan pengaruh profitabilitas, leverage, dan growth terhadap kebijakan dividen secara simultan, maka dilakukan uji F. Hasil analisis sebagaimana disajikan pada tabel 4.7 memberikan nilai $F_{\text {hitung }}=2,828$ dengan signifikansi 0,058. Ini berarti bahwa profitabilitas, Leverage, dan growth secara simultan (bersama-sama) berpengaruh positif tidak signifikan terhadap kebijakan dividen. Dengan demikian dapat disimpulkan bahwa hipotesis yang menyatakan bahwa profitabilitas, leverage, dan growth, secara simultan berpengaruh tidak signifikan terhadap kebijakan dividen, dengan ini dinyatakan ditolak kebenarannya.

Untuk mengetahui signifikansi pengaruh variabel profitabilitas, leverage, dan growth terhadap dividen secara parsial, maka dilakukan uji parsial (uji-t)

a. Pengaruh pofitabilitas terhadap kebijakan dividen

Variabel profitabilitas berpengaruh tidak signifikan terhadap kebijakan dividen. Rapat pemegang saham para pemegang saham dan pihak perusahaan menjelaskan laba yang telah didapatkan dapat dikelola dalam Di mana kebijakan deviden ditentukan dalam rapat umum pemegang saham, itu berarti bahwa deviden yang dibagikan tergantung pada perusahaan karena disesuaikan dengan perencanaan perusahaan kedepannya misalnya adanya ekspansi, atau apabila tidak ada ekspansi maka semakin besar laba maka deviden yang dibagikan juga besar.

b. Pengaruh leverage terhadap kebijakan dividen.

Leverage berpengaruh tidak signifikan terhadap kebijakan dividen. Penelitian in mendukung hasil penelitian yang dilakukan oleh Hartono (2000) menentukan bahwa kebijakan utang tidak mempengaruhi kebijakan dividen. Sunarto dan Kartika (2003) yang menemukan bahwa Debt to total assets tidak berpengaruh terhadap dividen kas dan Arilaha (2009) yang menyatakan bahwa leverage tidak berpengaruh terhadap kebijakan dividen. Perusahaan yang memiliki struktur permodalan terdiri dari kreditor dan pemegang saham, di mana pihak manajemen tidak hanya memperhatikan kepentingan kreditor berupa pelunasan kewajiban tetapi juga memperhatikan pemegang saham dengan membagikan dividen sel in itu kebijakan dividen tergantung pada perusahaan.

\section{c. Pengaruh growth terhadap kebijakan dividen}

Makin cepat tingkat pertumbuhan suatu perusahaan, makin besar kebutuhan dana untuk waktu mendatang untuk membiayai pertumbuhannya. Perusahaan tersebut biasanya akan lebih senang untuk menahan pendapatannya dari pada dibayarkan sebagai dividen dengan mengingat batas-batasan biayanya

Dari hasil uji $t$ maka $t$ hitung adalah 1,347 dan tingkat signifikansi sebesar 0,190 di mana diatas 0,05 yang 
artinya growth berpengaruh tidak signifikan terhadap kebijakan dividen. Berdasarkan hasil penelitian ketiga hipotesis ditolak.

\section{KESIMPULAN DAN SARAN}

Berdasarkan hasil penelitian dan pembahasan maka dapat diambil kesimpulan sebagai berikut:

1. Profitabilitas (ROI) berpengaruh negatif dan tidak signifikan terhadap perubahan Deviden payout ratio, yang berarti bahwa jika Profitabilitas (Return On Investment) meningkat maka arah perubahan Deviden Payout Ratio akan menurun .

2. Leverage (DER) berpengaruh negatif dan tidak signifikan terhadap perubahan Deviden Payout Ratio, yang berarti bahwa jika Debt to Equity Ratio meningkat maka arah perubahan Deviden Payout Ratio akan menurun.

3. Growth berpengaruh positif dan tidak signifikan terhadap perubahan Deviden Payout Ratio, yang berarti bahwa jika Growth meningkat maka arah perubahan Deviden Payout ratio juga akan meningkat.

Adapun saran-saran yang dapat dikemukakan dalam penelitian ini untuk pihak-pihak yang berkepentingan yaitu diharapkan perusahaan Manufaktur memperhatikan stabilitas keuntungan karena dapat memberikan gambaran bahwa perusahaan memiliki kualitas, serta berguna dalam pengambilan keputusan termasuk keputusan untuk membagikan deviden kepada para investor. Selain itu, perusahaan manufaktur tetap memperhatikan pertumbuhan perusahaan karena semakin besar suatu perusahaan berarti semakin besar kemampuan perusahaan menghasilkan laba yang berarti semakin besar kemampuan perusahaan membayar deviden.

\section{UCAPAN TERIMA KASIH}

Dalam penyelesaian karya ini, penulis berterima kasih yang sebesar-besarnya kepada seluruh pihak yang telah membantu yang tak bisa saya sebutkan satu persatu.

\section{DAFTAR PUSTAKA}

Arilaha, Muhammad Asril. 2009. Pengaruh Free Cash Flow, Profitabilitas, Likuiditas, dan Leverage terhadap Kebijakan Dividen.

Algifari. 2000. Analisis Regresi, Teori, Kasus, dan Solusi. Edisi 2. Yogyakarta: BPFE.

Brigham, Eugene F., and Louis C. Gapenski.,and Philips R. Daves., 1999. Intermediate Financial Management. Sixth Edition, The Dry den Press,Harcourt Brace Coilege Publisher, New York.

Darminto. 2008. Pengaruh Profitabilitas, Likuiditas, Struktur Modal Dan Struuktur Kepemilikan Saham, Terhadap Kebijakan Dividen.

Fauz dan Rosidi. 2007. Pengaruh Kebijakan Hutang (DER) dan Collateral Assets terhadap DPR.

Ghozali, lmam. 2005. Aplikasi Analisis Multivariate dengan Program SPSS. Semarang: BP Undip.

lslamiah, Rizki. 2012. Pengaruh Free Cash Flow, Profitabilitas, Likuiditas, Leverage, dan Growth terhadap Kebijakan Dividen pada Perusahaan Manufaktur di BEI.

Harahap Syafri, Sofyan. 2007. Analisis Kritis atas Laporan Keuangan. Jakarta: PT Raja Grafindo Persada.

Kasmir, 2011. Analisis Laporan Keuangan. Jakarta: PT Raja Grafindo Persada. 
Latiefasari, Hani Diana. 2011. Analisis faktor-faktor yang mempengaruhi Kebijakan Dividen (Studi Empiris pada Perusahaan Manufaktur yang Terdaftar di BEi Periode 2005-2009).

Prihantoro. 2003. Estimasi pengaruh DPR pada Perusahaan Publik 3 gi Indonesia. Jurnal Ekonomi dan Bisnis. Vol.14.No. 1.

Puspita, Fira. 2009. Pengaruh Cash Ratio, Growth, Firm Size, Return on Asset (ROA), Debt to Total Asset (OTA), dan Debt to Equity ratio (DER) terhadap Dividend payout Ratio (DPR).

Riyanto, Bambang. 2001. Dasar-Dasar Pembelanjaan Perusahaan. Edisi Keempat, Cetakan Ketujuh, Yogyakarta: BPFE.

Santoso, Singgih. 2002. SPSS Versi 10: Mengolah Data Statistik Secara Profesional. Jakarta: PT. Elex Media Komputindo.

Sartono. 2001. Kepemilikan Orang Dalam (Insider Ownership), Hutang, dan Kebijakan Dividen. Pengujian Empirik Teori Keagenan. JSB No 6.

Sulistyo, Andri Wardhana. 2011. Pengaruh Institusional Ownership, Likuiditas, Solvabilitas, Tingkat Pertumbuhan Terhadap Kebijakan Dividen Pada Perusahaan Manufaktur di Bursa Efek Indonesia. Skripsi. STIM NITRO Makassar.

Sulistiyowati, lndah, Ratna Aggraini, dan Tri Hesti Utaminingtyas, 2010 Pengaruh Profitabilitas, Leverage, Growth terhadap Kebijakan Dividen dengan Good
Corporate Goverment sebagai variabel Intervening.

Sutrisno. 2001. Pengaruh Posisi Kas, Potensi Pertumbuhan, Ratio Hutang dan Modal, Profitabilitas, Holding terhadap Dividend Payout Ratio.

Wahyudi dan Baldori. 2007. Pengaruh Insider Ownership, Collateralizable Assets, Growth In Assets, dan Likuiditas (Quick Ratio) terhadap kebijakan deviden pada perusahaan manufaktur yang listing di Bursa Efek Indonesia Periode 2002-2006

Weston, Freed and Thomas E. Coopeland. 2011. Indonesian Capital Market Directory. http://www.idx.co.id 